\title{
Penggunaan Mikro Irradiasi Sinar Gamma untuk Meningkatkan Keragaman Genetik pada Varietas Kedelai Argomulyo [Glycine max (L) Merr]
}

\author{
Diana Sofia Hanafiah ${ }^{1 *}$, Trikoesoemaningtyas ${ }^{2)}$, Sudirman Yahya ${ }^{2)}$ dan Desta Wirnas ${ }^{2)}$ \\ ${ }^{1)}$ Departemen Agroteknologi, Universitas Sumatra Utara, Medan 20155 \\ ${ }^{2}$ Departemen Agronomi dan Hortikultura, Intitut Pertanian Bogor, Bogor 16680 \\ Diterima 11-12-2009 Disetujui 02-06-2011
}

\begin{abstract}
This research used gamma ray irradiation on low doses (micro mutation). The aim of this research was to know the respons of doses level by micro mutation on gamma ray irridation to the growing and development of Argomulyo variety of Glycine max (L) Merr (M), the seeds is irradiated by gamma ray by micro mutation was $0 \mathrm{~Gy}, 50 \mathrm{~Gy}, 100 \mathrm{~Gy}, 150 \mathrm{~Gy}$, and $200 \mathrm{~Gy}$. Variation that obtained of each characters at generation $\mathrm{M}_{1}$ and $\mathrm{M}_{2}$ influences plants growth and development either through qualitative and quantitative that finally will influence plants production. The average highest genetic variation at $\mathrm{M}_{2}$ generation of soybean was on 200 Gy doses. Results of the research indicated that gamma ray irradiation on $200 \mathrm{~Gy}$ doses was effective caused of plant variation genetic.
\end{abstract}

Keyword: Argomulyo soybean variety, gamma ray irradiation, induced mutation, micro mutation

\section{PENDAHULUAN}

Berdasarkan perkiraan Badan Pusat Statistik (2009), produktivitas kedelai di Indonesia 1,2 - 1,3 ton/ha, sedangkan kebutuhan kedelai di Indonesia terus meningkat tiap tahunnya. Ini merupakan peluang sekaligus sebagai tantangan bagi para petani Indonesia untuk meningkatkan produksi kedelai dalam negeri. Departemen Pertanian menargetkan produksi kedelai nasional pada tahun 2009 sebanyak 850,230 ton atau naik 9,50 persen dibanding dengan tahun 2008 sebanyak 776,490 ton (Kompas 2009).

Tanaman menyerbuk sendiri, seperti tanaman kedelai akan membentuk galur-galur yang mantap atau tidak bersegregasi. Populasi tersusun dari galur-galur, dengan keragaman genetik intragalur sangat kecil atau hampir nol, dan keragaman antargalur sangat nyata. Keragaman genetik baru akan muncul di alam sebagai akibat mutasi atau terjadinya persilangan antargalur, walau dengan derajat yang kecil, sehingga keragaman genetik kedelai rendah (Jusuf 2004).

Diperkirakan daerah pusat distribusi dari genus Glycine adalah Asia Selatan dimana sebagian besar spesies endemik masih hidup, Daerah Cina dan Manchuria sekarang ini dapat ditemukan beberapa spesies liar kedelai, dan daerah sumber gen dari kedelai yang dibudidayakan, dimana masih terdapat kerabat spesies kedelai liar G. ussuriensis. Eksplorasi daerah sumber gen berhubungan dengan penyediaan sumber data dan plasma nutfah untuk perbaikan varietas dan pemuliaan serta adaptasi bagi kedelai yang dibudidayakan (Leppik 1971).

Kedelai di Indonesia bukan merupakan tanaman asli lokal Indonesia yang mempunyai keragaman genetik yang rendah. Untuk meningkatkan keragaman genetik dapat dilakukan dengan cara introduksi, persilangan dan mutasi. Varietas kedelai Argomulyo adalah salah satu varietas introduksi dari Thailand selain varietas introduksi lainnya seperti Bromo, Krakatau dan Tambora (Hidajat et al. 2000).

Peningkatan keragaman genetik tanaman kedelai akan mempermudah usaha dalam menyeleksi tanaman untuk mendapatkan suatu tanaman dengan sifat yang diinginkan, misalnya karakter tanaman untuk ketahanan terhadap cekaman kekeringan. Pemuliaan mutasi merupakan salah satu pemuliaan secara konvensional yang tidak membutuhkan waktu relatif lama untuk meningkatkan keragaman genetik tanaman.

Induksi tanaman dengan irradiasi sinar gamma merupakan salah satu cara dalam meningkatkan keragaman genetik tanaman. Pada penelitian ini menggunakan irradiasi sinar gamma pada tingkat atau dosis rendah (mutasi mikro) yang mempengaruhi perubahan karakter kuantitatif tanaman dan sedikit mempengaruhi perubahan kromosom dibandingkan dengan mutasi makro yang menggunakan irradiasi sinar gamma pada dosis yang tinggi. 
Dosis irradiasi sinar gamma yang direkomendasikan

International Atomic Energy Agency) untuk tanaman kedelai adalah pada penyinaran $200 \mathrm{~Gy}$, yang berguna untuk memperbaiki karakter kuantitatif tanaman. Dosis irradiasi ini berbeda untuk tiap kultivar dan spesies kedelai yang ada (Srisombun et al. 2009).

Mutasi induksi dapat dilakukan pada tanaman dengan mutagen tertentu terhadap organ reproduksi tanaman seperti biji, stek batang, serbuk sari, akar rhizome, kultur jaringan dan sebagainya. Apabila proses mutasi alami terjadi secara sangat lambat maka percepatan, frekuensi dan spektrum mutasi tanaman dapat diinduksi dengan perlakuan bahan mutagen tertentu (BATAN 2006).

Tujuan penelitian ini adalah mengetahui respon pemberian tingkat irradiasi mikro sinar gamma terhadap pertumbuhan dan perkembangan tanaman kedelai generasi pertama $\left(M_{1}\right)$ dan mengetahui keragaman genetik pada generasi kedua $\left(\mathrm{M}_{2}\right)$.

\section{BAHANDANMETODE}

Penelitian ini dilaksanakan di Institut Pertanian Bogor dari bulan Februari sampai Juni 2009. Penelitian ini untuk mengetahui keragaman tanaman pada generasi $\mathbf{M}_{1}$ dan pendugaan keragaman genetik yang disebabkan oleh irradiasi sinar gamma (generasi $\mathbf{M}_{2}$ ). Perlakuan irradiasi dilaksanakan di Pusat Sumberdaya Biologi dan Bioteknologi IPB Bogor dan penelitian lapangan dilaksanakan di Kebun Percobaan Cikabayan IPB Bogor.

Benih-benih varietas Argomulyo diirradiasi dengan sinar gamma dengan dosis 50 Gy, 100 Gy, 150 Gy and 200 Gy (micro doses) yang bersumber dari ${ }^{137} \mathrm{Cs}$ menggunakan IBL 437C type H Irradiator (CIS Bio International, France).

Sebanyak 200 benih $\left(M_{1}\right)$ pada masing-masing perlakuan dosis ditanam dengan jarak tanam 40 x $20 \mathrm{~cm}$ dan dievaluasi pengaruh dari irradiasi sinar gamma terhadap morfologi tanaman termasuk karakter bunga, daun, tinggi tanaman, jumlah cabang, jumlah polong produktif, jumlah polong hampa dan jumlah biji per tanaman. Pada generasi $\mathbf{M}_{1}$, tiap tanaman pada masing-masing dosis perlakuan dipanen 10 polong per tanaman (restricted bulk) yang akan ditanam sebagai generasi $\mathbf{M}_{2}$.

Benih-benih $\mathrm{M}_{2}$ ditanam 2000 benih per dosis perlakuan dengan jarak tanam 40 x $20 \mathrm{~cm}$ dan dievaluasi keragaman pada karakter agronomi termasuk tinggi tanaman, jumlah cabang, jumlah polong, jumlah polong hampa dan bobot biji per tanaman. Variasi genetik pada generasi $\mathbf{M}_{2}$ dihitung dengan rumus sebagai berikut:

$$
\sigma^{2}=\frac{\left(\sum x^{2}\right)-\left[\left(\sum x\right)^{2} / n\right]}{n-1}
$$

$\sigma^{2} \mathrm{M}_{2}=\sigma^{2} \mathrm{p}$

$\sigma^{2} \mathrm{p}=\sigma^{2} \mathrm{~g}+\sigma^{2} \mathrm{e}$

$\sigma^{2} g=\sigma^{2} p-\sigma^{2} e=\sigma^{2} M_{2}-\sigma^{2} M_{0}$

dimana:

$\sigma^{2}=$ ragam

$\mathrm{n}=$ jumlah anggota populasi

$\sigma^{2} \mathrm{p}=$ ragam fenotip

$\sigma^{2} \mathrm{~g}=$ ragam genotip

$\sigma^{2} \mathrm{e}=$ ragam lingkungan

$\sigma^{2} \mathrm{M}_{2}=$ ragam populasi $\mathrm{M}_{2}$

$\sigma^{2} M_{0}=$ ragam populasi $M_{0}$ (populasi Argomulyo sebagai kontrol)

Nilai heritabilitas dihitung dengan menggunakan rumus :

$$
\boldsymbol{h}^{2}=\frac{\sigma^{2} g}{\sigma^{2} p}(\text { Singh \& Chaudhari, 1977) }
$$

Kriteria nilai heritabilitas :

1. Jika nilai $\mathrm{h}^{2}>0,5 \quad$ : heritabilitas tinggi

2. Jika nilai $\mathrm{h}^{2}$ terletak antara $0,2-, 5:$ heritabilitas edang

3. Jika nilai $\mathrm{h}^{2}<0,2 \quad$ : heritabilitas rendah.

Variasi genetik ditentukan berdasarkan pada koefisien variasi genetik (KVG) menggunakan metode yang dikemukakan oleh Singh dan Chaudhari (1977), sebagai berikut :

$$
K V G=\left(\frac{\sigma_{g}}{-x}\right) \times 100 \%
$$

Dimana :

$\sigma_{\mathrm{g}}=$ akar varian genotip

$\frac{\mathrm{g}}{\bar{X}}=$ rata-rata nilai sifat

Nilai KVG mutlak yang tertinggi ditetapkan dari nilai KVG relatif $100 \%$.

\section{HASIL DAN PEMBAHASAN}

\section{Keragaan Tanaman M Hasil Mikro Mutasi Irradiasi}

Sinar Gamma. Hasil pengamatan menunjukkan bahwa pengaruh dosis irradiasi berpengaruh terhadap rataan karakter yang diamati, dimana terbentuk empat populasi baru yang berbeda dengan populasi kontrol (populasi 0 Gy). Perlakuan irradiasi mikro menghasilkan populasi yang berbeda dengan populasi kontrol (populasi yang tidak diiradiasi) terhadap karakter tinggi tanaman, jumlah polong, jumlah polong bernas, jumlah cabang dan jumlah biji, sedangkan pada karakter jumlah polong hampa tidak menyebabkan perubahan pada populasi tanaman yang telah diirradiasi (Tabel 1). 
Tabel 1 menunjukkan bahwa pemberian dosis irradiasi berpengaruh secara nyata terhadap tinggi tanaman. Populasi hasil irradiasi 50 Gy dan 100 Gy memiliki rataan tinggi tanaman yang tinggi dan berbeda nyata dibandingkan dengan populasi tanaman tanpa diirradiasi. Sakin (2002), menyatakan bahwa terjadi peningkatan rata-rata tinggi tanaman dibandingkan dengan kontrol setelah adanya irradiasi sinar gamma. Namun demikian seiring dengan pertambahan dosis irradiasi nilai tengah tinggi tanaman semakin menurun, hal ini sesuai dengan penelitian Pavadai et al. (2010), dimana laju induksi mutagen dan nilai tengah dari generasi $M_{1}$ menurun seiring dengan meningkatnya dosis sinar gamma yang diberikan.

Penelitian ini sama halnya seperti penelitian yang dilakukan Tah (2006), yang mengamati pengaruh perlakuan dosis terhadap tinggi tanaman pada turunan $\mathbf{M}_{1}$ Tah (2006), menyatakan bahwa pada tanaman kacang hijau Vigna radiata (L.) Wilczek] tinggi tanaman mengalami penurunan yang disebabkan oleh perlakuan dosis irradiasi sinar gamma $10 \mathrm{kRad}, 20 \mathrm{kRad}, 30 \mathrm{kRad}$ dan $40 \mathrm{kRad}(1 \mathrm{KRad}=10 \mathrm{~Gy})$, dimana penurunan tertinggi terjadi pada dosis $40 \mathrm{kRad}$. Hal yang sama juga terdapat pada penelitian Shakoor et al. (1978), menyatakan bahwa perlakuan pada kisaran dosis 10-30 kRad tidak berbeda nyata tetapi pada dosis $40 \mathrm{kRad}$ menyebabkan tanaman menjadi kerdil, dimana dosis $40 \mathrm{kRad}$ merupakan dosis tertinggi dan mendekati dosis letal (Lethal Doses 50) bagi tanaman kacang hijau, dan $L D_{50}$ mempunyai nilai yang berbeda pada masing-masing spesies tanaman.

Tabel 1 menunjukkan bahwa populasi hasil irradiasi 50 Gy dan 100 Gy memiliki rataan jumlah cabang yang tinggi dan berbeda nyata dibandingkan dengan populasi tanaman tanpa diirradiasi. Jumlah cabang yang terbentuk umumnya dua cabang pertanaman dan tidak jauh berbeda antara jumlah cabang tanaman kontrol dan tanaman hasil irradiasi. Pengaruh dosis maksimum terjadi pada dosis 50 Gy dengan peningkatan 25,5\% dibandingkan dengan kontrol.

Jumlah cabang pada dosis irradiasi 150 Gy lebih sedikit dari dosis 200 Gy, dimana pada 200 Gy terdapat cabang yang tidak produktif, tidak terbentuk polong dan bunga tidak berkembang. Hal ini disebabkan oleh adanya kerusakan fisiologis yang terjadi akibat irradiasi sinar gamma pada turunan $\mathrm{M}_{1}$. Sesuai dengan penelitian yang dilakukan oleh Ganguli dan Bhaduri (1980), menyatakan bahwa terjadi pengurangan cabang produktif akibat adanya irradiasi sinar gamma dan jumlah cabang utama lebih banyak dari pada kontrol pada setiap perlakuan dosis yang diberikan. Penelitian lain pada tanaman Lepidium sativum L. juga menunjukkan bahwa semakin tinggi dosis irradiasi yang diberikan, terjadi penurunan jumlah cabang (Majeed et al. 2010).

Penelitian yang dilakukan Tah (2006), menyatakan bahwa pengaruh dosis irradiasi sinar gamma terhadap jumlah cabang pada dosis $30 \mathrm{kRad}$ meningkat sebesar 30,55\% dibanding dengan kontrol. Sehingga, dengan meningkatnya jumlah cabang produktif, jumlah polong per tanaman akan meningkat.

Tabel 1 menunjukkan bahwa pengaruh irradiasi sinar gamma menyebabkan rataan jumlah polong yang tinggi pada populasi hasil irradiasi dibandingkan populasi kontrol dengan peningkatan yang bervariasi. Jumlah polong tertinggi terdapat populasi hasil irradiasi $150 \mathrm{~Gy}$, yakni terjadi peningkatan sebesar $27,33 \%$ dimana polong lebih banyak terbentuk pada batang utama dibandingkan populasi kontrol. Peningkatan jumlah polong pada $\mathrm{M}_{1}$ juga terjadi pada penelitian Tah (2006), dimana peningkatan jumlah polong akibat adanya irradiasi sinar gamma mencapai 15-23\% dan mencapai jumlah maksimum pada dosis irrradiasi $30 \mathrm{kRad}$.

Pada populasi tanaman hasil penyinaran dosis irradiasi $200 \mathrm{~Gy}$, jumlah polong yang terbentuk lebih sedikit, banyak bakal bunga tidak berkembang dan bunga tidak berkembang membentuk polong (mengalami sterilitas dan keabnormalan perkembangan). Tabel 1 menunjukkan bahwa jumlah polong hampa tidak berbeda nyata pada setiap dosis irradiasi. Pada tanaman $M_{1}$ polong hampa tertinggi terjadi pada populasi hasil irradiasi $200 \mathrm{~Gy}$, dimana polong yang terbentuk tidak berisi. Hal ini disebabkan biji gagal terbentuk disebabkan adanya gangguan perkembangan pada tanaman akibat irradiasi sinar gamma.

Tabel 1 Rataan karakter tanaman $M_{1}$ hasil mikro mutasi irradiasi sinar gamma

\begin{tabular}{|c|c|c|c|c|c|c|}
\hline \multirow[t]{2}{*}{ No. } & \multirow[t]{2}{*}{ Karakter } & \multicolumn{5}{|c|}{ Populasi Irradiasi } \\
\hline & & 0 & 50 & 100 & 150 & 200 \\
\hline 1 & Tinggi Tanaman $(\mathrm{cm})$ & 34,20 & $38,00^{*}$ & $37,88^{*}$ & 36,42 & 30,47 \\
\hline 2 & Jumlah Cabang (buah) & 1,75 & $2,35^{*}$ & $2,30 *$ & 1,90 & 2,20 \\
\hline 3 & Jumlah Polong (buah) & 27,65 & $36,25^{*}$ & $35,75 * *$ & $38,05 * *$ & 29,20 \\
\hline 4 & Jumlah Polong Bernas (buah) & 27,35 & $35,90 *$ & $35,40 * *$ & $37,70 * *$ & 28,65 \\
\hline 5 & Jumlah Polong Hampa (buah) & 0,35 & 0,35 & 0,35 & 0,35 & 0,45 \\
\hline 6 & Jumlah Biji & 70,60 & $88,35^{*}$ & 78,05 & $83,40 *$ & $56,35 *$ \\
\hline
\end{tabular}


Pada rataan jumlah biji, populasi hasil irradiasi 50 Gy memiliki rataan tertinggi dibandingkan dengan populasi tanpa kontrol, sedangkan populasi hasil irradiasi 200 Gy memberikan rataan jumlah biji yang rendah dan berbeda nyata dari populasi hasil irradiasi lainnya. Pada populasi hasil irradiasi $200 \mathrm{~Gy}$, jumlah biji per tanaman lebih kecil dibandingkan dengan populasi hasil irradiasi lainnya. Pada penelitian ini didapatkan bahwa jumlah biji per tanaman kedelai varietas Argomulyo yang diirradiasi sinar gamma pada dosis 50 Gy, 100 Gy dan 150 Gy lebih tinggi dari pada populasi kontrol. Namun demikian seiring dengan pertambahan dosis irradiasi rataan jumlah biji semakin menurun. Berdasarkan penelitian Kumar et al. (2010), bahwa penurunan hasil biji per tanaman dengan meningkatnya dosis irradiasi sinar gamma berhubungan dengan pengaruh tidak langsung adanya perubahan pada komponenkomponen hasil, seperti penurunan tinggi tanaman, jumlah polong dan tingkat sterilitas biji.

Gambar 1 menunjukkan bahwa irradiasi sinar gamma mempengaruhi keragaman fenotip pada turunan $\mathbf{M}_{1}$ berdasarkan ciri-ciri morfologi tanaman. Hal ini ditunjukkan oleh adanya perubahan yang bersifat kualitatif seperti perubahan bentuk daun dari bulat telur (normal) menjadi memanjang, terdapat daun bifoliat dan unifoliat di atas buku pertama yang berada pada satu tanaman dengan daun trifoliat, perubahan warna bunga dari ungu menjadi putih, tidak berkembangnya rasim bunga menjadi polong, serta daun masih hijau walaupun polong telah matang panen.
Perubahan yang bersifat kualitatif ini terjadi pada beberapa tanaman pada populasi hasil irradiasi 150 Gy dan 200 Gy. Hal yang sama juga terjadi pada induksi mutasi dengan irradiasi sinar gamma pada kedelai (Manjaya \& Nandawar 2007), dan kacang hijau (Sangsiri et al. 2005), yang menunjukkan terjadinya perubahan pada bentuk dan warna daun serta bentuk dan warna bunga dan ada juga menimbulkan sterilitas pada tanaman.

Variasi Genetik dan Heritabilitas Generasi $M_{2}$ Hasil Irradiasi Sinar Gamma. Benih-benih yang dipanen dari tanaman $\mathrm{M}_{1}$ merupakan benih-benih $\mathrm{M}_{2}$ dan ditanam sebagai tanaman $M_{2}$ yang diharapkan menunjukkan segregasi pada lokus-lokus yang mengalami mutasi. Variasi genetik dapat diamati pada generasi $\mathbf{M}_{2}$. Pada penelitian ini, pengamatan difokuskan pada karakter agronomi seperti tinggi tanaman, komponen hasil dan hasil. Variasi genetik dan heritabilitas populasi tanaman $M_{2}$ varietas kedelai Argomulyo pada berbagai dosis irradiasi dapat dilihat pada Tabel 2.

Rata-rata tinggi tanaman cenderung meningkat seiring dengan meningkatnya dosis irradiasi (Tabel 2). Bagaimanapun, pada populasi hasil irradiasi 200 Gy ratarata tinggi tanaman rendah dibandingkan rata-rata tinggi tanaman pada dosis yang lain. Rata-rata jumlah cabang produktif mempunyai nilai tertinggi pada populasi hasil irradiasi 200 Gy dan nilai terendah terdapat pada populasi hasil irradiasi $150 \mathrm{~Gy}$. Nilai rata-rata tertinggi jumlah buku produktif juga terdapat pada populasi hasil irradiasi $200 \mathrm{~Gy}$ dan nilai terendah terdapat pada populasi hasil irradiasi

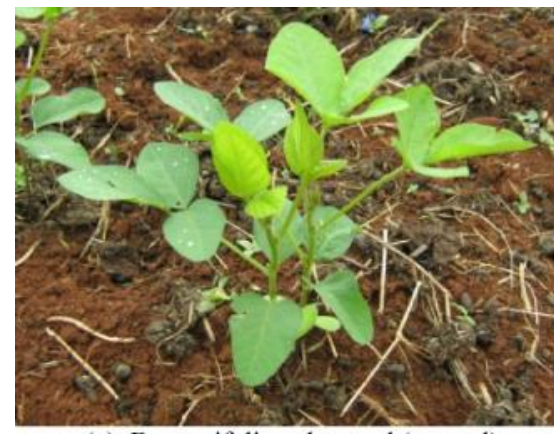

(a). Daun trifoliate dan oval (normal)

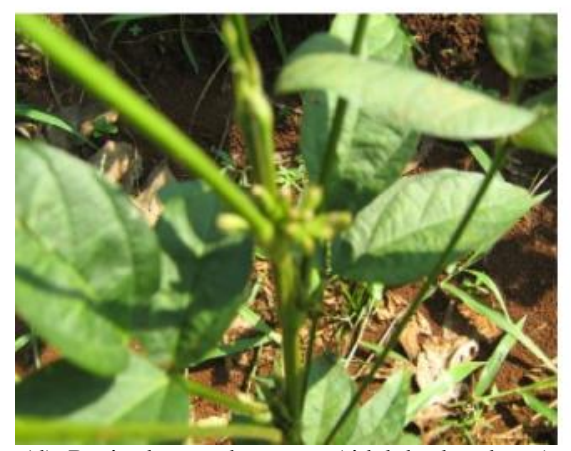

(d). Rasim bunga dan tunas (tidak berkembang)

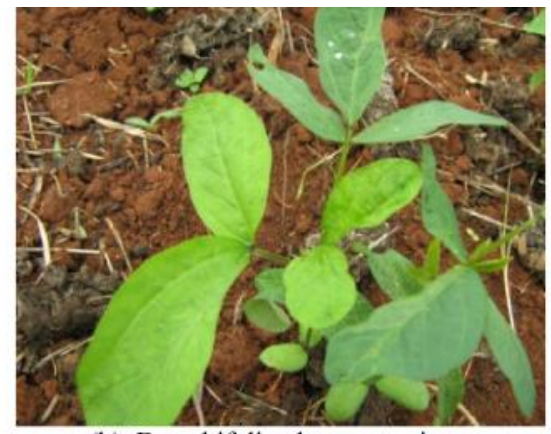

(b). Daun bifoliat dan memanjang

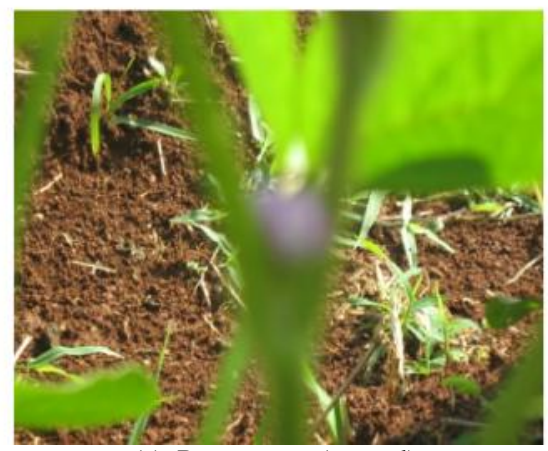

(e). Bunga ungu (normal)

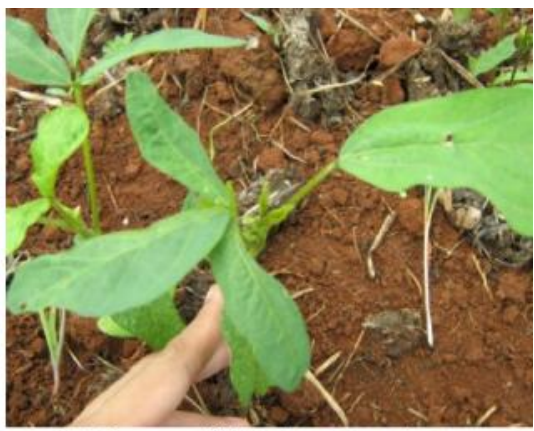

(c). Daun unifoliat dan memanjang

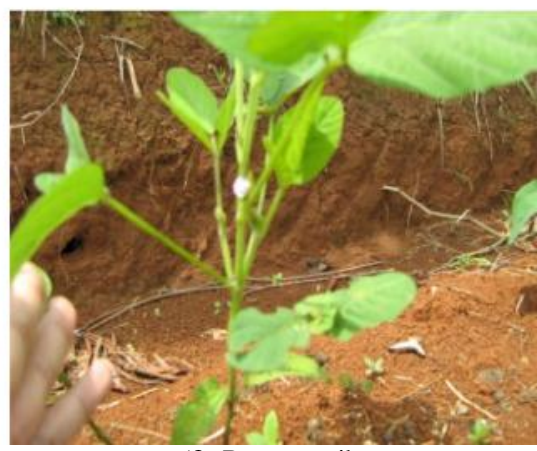

(f). Bunga putih

Gambar 1 Keabnormalan pertumbuhan tanaman kedelai varietas Argomulyo akibat irradiasi sinar gamma 
50 Gy. Nilai rata-rata tertinggi jumlah polong produktif juga terdapat pada populasi hasil irradiasi 200 Gy dan nilai terendah terdapat pada populasi hasil irradiasi $150 \mathrm{~Gy}$. Nilai rata-rata tertinggi jumlah polong hampa terdapat pada populasi hasil irradiasi $200 \mathrm{~Gy}$ dan nilai terendah terdapat pada populasi hasil irradiasi $50 \mathrm{~Gy}$. Sedangkan nilai ratarata bobot biji per tanaman tertinggi terdapat pada populasi hasil irradiasi $50 \mathrm{~Gy}$.

Keragaman genetik meningkat seiring dengan meningkatnya dosis irradiasi adalah pada peubah amatan tinggi tanaman, jumlah buku produktif dan jumlah polong. Untuk semua karakter yang diamati, keragaman genetik tertinggi terdapat pada populasi hasil irradiasi $200 \mathrm{~Gy}$. Dosis irradiasi sinar gamma yang direkomendasikan oleh IAEA (International Atomic Energy Agency) untuk tanaman kedelai adalah pada penyinaran $200 \mathrm{~Gy}$, yang berguna untuk memperbaiki karakter kuantitatif tanaman (Srisombun et al. 2009).

Pada karakter yang lain, keragaman genetik tidak meningkat secara proporsional dengan meningkatnya dosis irradiasi seperti yang diamati pada jumlah cabang produktif dan bobot biji per tanaman. Berdasarkan pengamatan pada keragaman genetik menunjukkan bahwa dosis irradiasi yang rendah akan menghasilkan keragaman dari karakter-karakter yang diinginkan. Sakin (2002), juga mengamati mutasi pada karakter-karakter kuantitatif dari gandum pada dosis rendah irradiasi sinar gamma. Keuntungan dari penggunaan dosis rendah irradiasi memungkinkan terjadinya mutasi pada gen-gen minor yang diamati pada generasi lanjut tanpa terjadi mutasi yang merugikan. Sangsiri et al. (2005), menyatakan bahwa banyak mutasi yang merugikan seperti albino dan perubahan bentuk daun pada kacang hijau setelah perlakuan irradiasi pada dosis $500 \mathrm{~Gy}$.

Keragaman dari karakter-karakter agronomi pada kedelai setelah diirradiasi sinar gamma adalah dikendalikan secara genetik. Keragaman genetik yang tinggi sangat penting pada proses seleksi karena respon genetik untuk seleksi tergantung pada tingkat keragaman genetik (Hallauer 1987). Nilai duga heritabilitas arti luas yang tinggi ditemukan pada peubah amatan tinggi tanaman dan jumlah polong produktif. Ini berarti bahwa seleksi untuk perbaikan dari

Tabel 2 Variasi genetik dan heritabilitas populasi $\mathrm{M}_{2}$ pada berbagai dosis irradiasi

\begin{tabular}{|c|c|c|c|c|c|}
\hline \multirow[t]{2}{*}{ No } & \multirow[t]{2}{*}{ Karakter } & \multicolumn{4}{|c|}{ Populasi Irradiasi } \\
\hline & & 50 & 100 & 150 & 200 \\
\hline \multirow[t]{6}{*}{1} & Tinggi Tanaman & & & & \\
\hline & $\bar{x}$ & 32,76 & 33,14 & 34,73 & 34,43 \\
\hline & $\sigma^{2} \mathrm{p}$ & 12,953 & 13,492 & 24,824 & 28,060 \\
\hline & $\sigma^{2} g$ & 7,092 & 7,630 & 18,962 & 22,198 \\
\hline & $\mathrm{h}^{2}$ & 0,547 & 0,565 & 0,764 & 0,791 \\
\hline & KVG $(\%)$ & 8,129 & 8,334 & 12,536 & 13,683 \\
\hline \multirow[t]{6}{*}{2} & Jumlah cabang produktif & & & & \\
\hline & $\bar{x}$ & 2,73 & 2,81 & 2,48 & 3,01 \\
\hline & $\sigma^{2} \mathrm{p}$ & 2,572 & 1,055 & 1,237 & 0,951 \\
\hline & $\sigma^{2} g$ & 1,924 & 0,406 & 0,588 & 0,302 \\
\hline & $h^{2}$ & 0,748 & 0,385 & 0,475 & 0,317 \\
\hline & KVG $(\%)$ & 50,785 & 22,645 & 30,810 & 18,276 \\
\hline \multirow[t]{6}{*}{3} & Jumlah buku produktif & & & & \\
\hline & $\bar{x}$ & 17,24 & 18,00 & 17,28 & 19,02 \\
\hline & $\sigma^{2} \mathrm{p}$ & 15,587 & 23,611 & 25,468 & 24,507 \\
\hline & $\sigma^{2} \mathrm{~g}$ & 1,105 & 8,611 & 12,468 & 14,507 \\
\hline & $h^{2}$ & 0,071 & 0,365 & 0,490 & 0,592 \\
\hline & KVG $(\%)$ & 6,097 & 16,302 & 20,431 & 20,024 \\
\hline \multirow[t]{6}{*}{4} & Jumlah polong produktif & & & & \\
\hline & $\bar{x}$ & 39,08 & 38,13 & 38,07 & 43,19 \\
\hline & $\sigma^{2} \mathrm{p}$ & 111,368 & 220,605 & 191,209 & 209,976 \\
\hline & $\sigma^{2} g$ & 36,013 & 145,251 & 115,855 & 134,622 \\
\hline & $\mathrm{h}^{2}$ & 0,323 & 0,658 & 0,606 & 0,641 \\
\hline & KVG $(\%)$ & 15,355 & 31,601 & 28,269 & 26,862 \\
\hline \multirow[t]{6}{*}{5} & Jumlah polong hampa & & & & \\
\hline & $\bar{x}$ & 1,40 & 2,53 & 2,60 & 3,05 \\
\hline & $\sigma^{2} \mathrm{p}$ & 2,783 & 5,792 & 4,866 & 7,705 \\
\hline & $\sigma^{2} g$ & 0,131 & 3,140 & 2,214 & 5,053 \\
\hline & $h^{2}$ & 0,047 & 0,542 & 0,455 & 0,655 \\
\hline & KVG $(\%)$ & 25,882 & 70,015 & 57,237 & 73,578 \\
\hline \multirow[t]{6}{*}{6} & Bobot biji per tanaman & & & & \\
\hline & $\bar{x}$ & 10,93 & 9,85 & 9,47 & 10,17 \\
\hline & $\sigma^{2} p$ & 10,775 & 16,458 & 16,574 & 12,116 \\
\hline & $\sigma^{2} g$ & 0,033 & 5,716 & 5,832 & 1,374 \\
\hline & $\mathrm{h}^{2}$ & 0,003 & 0,347 & 0,352 & 0,113 \\
\hline & $\operatorname{KVG}(\%)$ & 1,664 & 24,257 & 25,494 & 11,521 \\
\hline
\end{tabular}


dua karakter ini dapat dilakukan untuk menghasilkan genotipe dengan tinggi tanaman dan produksi yang diinginkan. Untuk karakter-karakter yang lain, nilai duga heritabilitas berkisar dari sedang sampai rendah. Sakin(2002), melakukan pengamatan pada gandum bahwa nilai heritabilitas untuk beberapa populasi mutan tergantung pada karakterkarakter yang diamati.

\section{SIMPULAN}

Variasi-variasi fenotip yang terjadi pada tanaman $\mathrm{M}_{1}$ disebabkan oleh adanya perubahan yang terjadi akibat efek dari irradiasi sinar gamma, dimana mempengaruhi pertumbuhan dan perkembangan tanaman.

Variasi genetik pada tanaman generasi $\mathrm{M}_{2}$ tertinggi rata-rata terjadi pada perlakuan $200 \mathrm{~Gy}$. Hal ini berarti bahwa irradiasi sinar gamma pada dosis 200 Gy efektif menyebabkan terjadinya keragaman genetik pada tanaman.

\section{UCAPANTERIMAKASIH}

Penulis mengucapkan terima kasih kepada DP2M Dikti melalui Proyek IMHERE IPB yang telah mendanai penelitian ini sehingga penelitian ini dapat terlaksana.

\section{DAFTAR PUSTAKA}

Badan Pusat Statistik. 2009. Produksi, Luas panen dan produktivitas palawija di Indonesia. http://www.deptam.go.id/infoeksekutif/tan/ TPARAMI-7/07/PalawijaNasional.htm (12 April 2009).

BATAN. 2006. Mutasi dalam Pemuliaan Tanaman http:// www.batan.go.id/patir/pert/pemuliaan/pemuliaan.html (15 Juli 2007).

Ganguli, P. \& Bhaduri, P. 1980. Effect x-rays and thermal neutrons on dry seeds of Greengram (P. aureus). Genetica Agraria 34: $257-276$

Hallauer, A.R. 1987. Maize. Di dalam : Fehr, W.R (Ed). Principles of cultivar development crops specie New York : Machmillan Publishing Company, A Division Macmillan Inc 2: 249-294.

Hidajat, J.R., Harnoto, Mahmud, M. \& Sumarno. 2000. Teknologi Produksi Benih Kedelai. Bogor: Pusat Penelitian dan Pengembangan Tanaman Pangan.

Jusuf, M. 2004. Metode Eksplorasi, Inventarisasi, Evaluasi dan Konservasi Plasmanutfah, Pusat Penelitian Bikoteknologi IPB. Bogor. http://www.papua.go.id/bkp bapedalda/index.htm (15 Juli 2007).

Kompas. 2009. Petani Enggan Tanam Kedelai. Jakarta : Terbit Tanggal 11 Maret 2009.

Kumar, V.A., Kumari, R.U., Vairam, N. \& Amutha, R. 2010. Effect of physical mutagen on expression of characters in arid legume pulse cowpea (Vigna unguiculata (L.) Walp.). Journal of Plant Breeding 1(4): 908-914.

Leppik, E.E. 1971. Assumed gene centers of peanuts and soybeans. Economic Botany Journal 25(2): 188-194.

Majeed, A., Khan, A.U.R., Ahmad, H. \& Muhammad, Z. 2010. Gamma irradiation effect on some growth parameters of Lepidium sativum L. Journal of Agricultural and Biological Science 5(1): 39-42.

Manjaya, J.G. \& Nandanwar, R.S. 2007. Genetic improvement ot soybean vanety JS 80- 21 through induced mutations. Plant Mutation Reports 1(3): 36-40.

Pavadai, P., Girija, M. \& Dhanavel. 2010. Effect of gamma rays on some yield parameters and protein content of soybean in $\mathrm{M}_{2}, \mathrm{M}_{3}$ and $\mathrm{M}_{4}$ generation. Journal of Experimental Sciences 1(6): 8-11.

Sakin, M.A. 2002. The Use of Induced Micro-Mutation for Quantitative Characters after EMS and Gamma Ray Treatments in Durum Wheat Breeding. Pakistan Journal of Applied Sciences 2(12): 1102-1107.

Sangsiri, C., Sorajjapinun, W. \& Srinives, P. 2005. Gamma radiation induced mutations in mungbean. ScienceAsia 31: 251-255.

Shakoor, A., Ahsan-ul-haq, M. \& Sadiq, M. 1978. Induced variation in mungbean. Environmental Experimental Botany 18: $169-175$.

Singh, R.K. \& Chaundhary, B.D. 1977. Biometrical Methods in Quantitative Genetics Analysis. New Delhi: Kalyani Publishers.

Srisombun, S., Benjamas, K., Chitima, Y. \& Jeeraporn, K. 2009. Soybean Variety Improvement for High Grain Protein Content Using Induced Mutation. IAEA/RCA project RAS/5/045. Vietnam, 16-20 Februari 2009.

Tah, P.R. 2006. Studies on gamma ray induced mutations in mungbean [Vigna radiata (L.) Wilczek]. Asian Journal of Plant Science 5(1): 61-70. 